\title{
Practice Leader Role in Developing Resource Teachers: Learning and Behaviour Professional Identity through Induction
}

\author{
Joanne Arnold
}

\section{ABSTRACT}

This research paper centres on a professional inquiry across Resource Teachers: Learning and Behaviour (RTLB) clusters within New Zealand that explored the role induction played in the ongoing development of new RTLB's professional identity. A review of the literature was timely as although the RTLB service has the RTLB Toolkit ${ }^{1}$, induction practices vary across the country. There is no 'set' framework that all RTLB use, and evolvement of professional identity is not mentioned within the RTLB Toolkit. Through anonymous online surveys to both new RTLB to the service in the last three years, and Practice Leaders (PLs), participants shared key factors they believed supported the development of their professional identity through their induction framework. The research results highlighted six key components of an effective induction process that could foster professional identity growth. They were consistency of induction, clarity and understanding around what is professional identity, developing and maintaining trusting relationships, the importance of ako, Communities of Practice (COP) and the impact of RTLB training on professional identity.

\section{Research paper}

\section{Keywords:}

ako, communities of practice, induction, practice leaders, professional identity, relationships, RTLB

\section{INTRODUCTION}

Becoming a new teacher/RTLB involves a process of 'identity change' (Palmér, 2016). One of the challenges I faced when I first became an RTLB after 22 years of teaching was around my professional identity. As an experienced teacher, I had an established professional identity; however, I now had to adjust and look at this through a different lens. RTLB are still teachers, but they are supporting

\footnotetext{
${ }^{1}$ A toolkit of information and resources that support clusters in their governance, management and professional practice. The toolkit includes information about avenues of support for RTLB. It also provides the policy and guiding principles for RTLB to which they must adhere (TKI, 2017)
}

ākonga differently; therefore my professional identity had to evolve. My concern was that I felt my cluster's induction process did not formally support this and I was interested in seeing if this was a nationwide phenomenon.

Professional identity is multi-layered and continuously developing, but at the heart it is around who we are and what we do as teachers (Hsieh, 2015). I was interested in how PLs could support the development of professional identity of new RTLB through induction. Induction in this context is focused on what our role as an RTLB is. Kelchtermans (2009) describes professional identity as having key components which include the perception of the job and job motivation. I saw induction as an extensive framework of support; however, it would appear from professional discussions with new RTLB and PLs, that identity development is never quite explored, and for the most part, it is notably absent from the start.

Research demonstrates that induction that is ongoing and effective can be viewed as one of the most valuable exercises in supporting the transition of new teachers/RTLB into the profession (Gujarati, 2012; Kang \& Berliner, 2012; Kearney, 2013; Serpell, 2000; Wojnowski, Bellamy, \& Cooke, 2003). Within this review, induction is essentially a process of learning; in other words, making connections between learning opportunities and experiences, and creating goals around the Practising Teacher Criteria (PTC) ${ }^{2}$ that every teacher /RTLB must meet within a three year attestation process.

As an RTLB PL, I have been involved over the last few years in supporting the induction of new RTLB into the service. Through observations and discussions, it appeared that the induction process of new RTLB should include opportunities for new RTLB to explicitly consider their professional identity and the shifts in their identities as they grow as RTLB.

\footnotetext{
${ }^{2}$ The Practising Teacher Criteria (Criteria) describe the essential knowledge and capabilities required for quality teaching in New Zealand. They apply to all teachers in their everyday professional practice seeking to be issued with a full practising certificate, or renew full certification (Education Council, 2017)
} 
The aim of this paper was to identify key indicators within the induction process of new RTLB that were crucial to support the ongoing development of their professional identity. At the heart of this was the examination of the role and support provided by PLs to new RTLB through cluster induction processes to support identity development.

\section{Background to RTLB Service}

RTLB are a group of specialised professionals who work interprofessionally with schools, teachers, agencies such as Ministry of Education Learning Support, and Years 1-10 students who experience identified learning and behaviour difficulties. There are forty geographically defined groups (clusters) across New Zealand employing approximately nine hundred and twenty nine RTLB (Ministry of Education, 2015). To become an RTLB, applicants need to be an experienced teacher ( 5 years or more) and gain a Postgraduate Diploma in Specialist Teaching through Massey/Canterbury Universities. This two year course has a strong focus on developing professional identity. This research examined if what the postgraduate programme was trying to do was actually occurring in the field i.e. was RTLB professional identity being fostered?

To become a PL, there is no set requirement around leadership experience or time as RTLB. PLs are "responsible for leadership, guidance and support of RTLB in their professional practice" (Ministry of Education, 2016, p. 47). Part of this role is the overseeing of the induction process. Induction is a multi-faceted process (Bickmore \& Bickmore, 2010; Henry, Bastian \& Fortner, 2011) and includes mentoring and coaching, supporting reflective practice, ensuring new RTLB have a commitment to evidence-based practice and are culturally competent in their practice.

\section{LITERATURE REVIEW}

\section{Induction}

Induction could be viewed as a 'phase', not merely a programme with a focus on teacher learning, not just teacher support/needs (Britton, Paine, Pimm, \& Raizen, 2003; Feiman-Nemser, Carver, Schwille, \& Yusko, 1999; Feiman-Nemser, 2001). For newly qualified teachers this period or phase can either be easily navigated or fraught with difficulties. The literature shows that teachers deal with numerous difficulties during their induction period such as poor mentoring, contradictions between theory and practice (Green, 2014; Henry, Bastian \& Fortner, 2011; Kearney, 2016; Luft, 2007).
Currently, newly qualified teachers in New Zealand are supported by a key document entitled Guidelines for Induction and Mentoring and Mentor Teachers' (NZTC, 2015). Previously, induction was viewed as a programme that provided 'advice, guidance and emotional support.' However, current concepts of induction conceive it as a reciprocal learning process which is co-constructional, providing opportunities for 'learning conversations' and focusing on evidence of teacher practice (NZTC, 2015). A role of induction is to strengthen the identities of participants by incorporating their past and present knowledge and learning into the practice of the community (Wenger, 1998).

Over the last decade, research has highlighted crucial elements of effective induction. These include:

- the one- to two-year mandated programme that focused on teacher learning and evaluation

- the provision of a mentor

- the opportunity for collaboration

- structured observations

- reduced teaching and/or release time

- intensive workplace learning

- beginning teacher seminars and/or meetings

- professional support and/or professional networking

- part of a programme of professional development

(Kearney, 2014, pp. 12-13)

These key characteristics are also evident within the Guidelines for Induction and Mentoring and Mentor Teachers (NZTC, 2015). This document emphasises that induction for teachers in New Zealand should: be tailored to the individual needs of the teacher; include regular observations of their teaching practice; include time for 'learning conversations' where the mentor provides feedback and helps to facilitate critical reflection by the teacher on their practice; and encourage to be part of the wider learning community (NZTC, 2011). While these are guidelines for teacher induction in New Zealand, Cameron (2007) argues that "comprehensive induction programs vary in their particular design, but essential elements include a high quality mentor program, on-going professional development, access to an external network of beginning teachers and standards-based evaluations of beginning teachers and the program itself".

The role of induction with new RTLB is complex and while the RTLB Toolkit (2016) does provide expectations regarding RTLB induction there is no detailed framework or principles around induction. 
Some of these references are "induction includes familiarisation with the cluster needs analysis and strategic plan" and "access to an academic mentor, to support the appointee during training" (Ministry of Education, 2016, pp. 43 - 44). As experienced teachers, RTLB also have to provide evidence against the PTC, yet the context they work in is different to that of a classroom teacher. Carroll, Fulton, Yoon and Lee (2005), Feiman-Nemser (2001), and Totterdell et al., (2004) stress that teacher induction should not be a one-off event occurring within the early stages of their career, but rather that it should be ongoing and integrated into their professional learning journey. As experienced teachers, RTLB should view induction as an extension of their professional journey.

Anecdotal evidence from new RTLB suggests that there is a disconnect when it comes to transferring what they have learned as a teacher to their new role: their self-efficacy was affected. For instance, working closely with students and teachers does not necessarily transfer to working effectively with parents. Bandura's (1989) concept of self-efficacy has been significantly linked with research around teacher induction (Duffin, French \& Patrick, 2012; Garvis, 2009; Ross \& Bruce, 2007; TschannenMoran, Hoy, \& Hoy 1998; Tschannen-Moran \& Hoy, 2001). Bandura (1977) claims that a teacher's level of self-efficacy might not be the same for each specific task. For new RTLB, their level of self-efficacy is crucial. We could argue that increasing self-efficacy in new RTLB is a key reason for providing an effective induction framework that provides on-going feedback on performance.

\section{Professional Identity}

The term professional identity in relation to the teaching profession is one that has been the focus of numerous studies over the last decade (Heggen, 2008; Hsieh, 2014; Izadinia, 2014; Kreber, 2010; Luehmann, 2007; Palmér, 2016; Ruohotie-Lyhty, 2013; Settlage et al., 2009). For Feiman-Nemser (2001), one of the key purposes of teacher induction is supporting new teachers as they "gain and develop a professional identity". As a lifelong learning process, identity is shaped by social relations and processes (Berger \& Luckmann, 1991). One could argue that teacher identity is also shaped through social and occupational contexts, personal theories of teaching and perceptions of self (Kreber, 2010).

Professional identity within this review was seen as not the static property of a teacher but rather a practice that developed, changed, or was opposed as teachers negotiated forms of participation in a teacher community, built upon professional and experiential knowledge and recognising themselves as performing a professional role (Heggen, 2008; Izadinia, 2014). This development of expertise where new teachers/ RTLB constantly set new goals and challenges, and form and reform themselves is part of identity development (Luehmann, 2007; Settlage, Southerland, Smith \& Ceglie, 2009; Tsui, 2003). We can argue that professional identity does not occur simply from the build-up of experiences; rather it is a "path that is created as the individual moves from one event or context to the next" (Settlage et al., 2009, p. 105).

Even though there is no single definition of what constitutes professional identity, there are some common features:

- Teachers have multiple professional identities - RTLB would be different to a high school mathematics teacher, who in turn would be different to a primary school teacher (Beijaard, Meijer \& Verloop, 2004; Sachs, 2001; Schifter, 1996)

- It focuses on the whole rather than on part of a person - it concentrates on the becoming rather than the knowing (Palmér, 2016)

- It is a continuing and dynamic process with multi influences from educational, social, historical and cultural contexts (Ponte \& Chapman, 2008, Beijaard, Meijer \& Verloop, 2004)

- It is neither totally collective nor totally individual - may share similar attributes, but goals and knowledge may differ

(Beijaard, Meijer, \& Verloop, 2004)

A clearer view of how crucial professional identity is to all professionals including RTLB is gained when it is examined within a theoretical framework. One way of viewing the development and mentoring of professional identity is that it is a way each of us 'stories' ourselves over time through the contexts we work in and the interactions we have with people within these contexts (Kelchtermans, 2009). When devising an induction framework, Kelchtermans suggests focusing on fostering and supporting an individual's self-esteem, their self-image, clarity around what is expected of their teaching role, job motivation, and supporting future directions and professional development (p. 257). It is important to note here that this is not an exhaustive 'tick list', but rather these five aspects are a continuum and are interrelated and dynamic.

It can be surmised that professional identity is perceived as a continuous process of understanding and re-understanding of experiences within the profession and the interactions with more experienced colleagues (Beijaard et al., 2004; Day 1999; Kerby 1991; Saka, Southerland \& Brooks, 
2009). This new learning incorporates a vast array of "concepts and structures, conventions, processes, skills, pleasure, satisfaction and frustration, aesthetics, a sense of wonder, and perhaps other aspects into a unit of analysis" (Lerman, 2009, p. 157). It does not provide answers to the question of 'who am I at this present moment?' but, instead, it focuses on 'who I want to become' (Beijaard et al., 2004). One could argue that this new learning could include being part of a mentoring programme, contributing to CoP, participating in further professional development. It is possible through a formal induction program that these key aspects can be addressed by PLs. These links between induction and professional identity will be explored in the following section.

\section{Building Relationships}

The formation of collaborative, mentoring relationships between participants plays a vital role in the development of professional identity (Hall \& Burns, 2009; Hattie, 2016; Kram, 1985; Lave \& Wenger, 1991). By providing emotional and academic support through mentoring, PLs are ensuring they are helping to build professional identity through induction. Dobrow and Higgins' (2005) research suggested that if a person has limited access to a network of support, then their clarity around their professional identity decreases.

Although traditional one on one mentoring occurs, there is now a stronger emphasis on multi relationships such as CoP and supervision triads. These more diverse networks can offer a variety of support, information, and resources for professional identity construction. (Dobrow \& Higgins, 2005) Morgan, et, al, 2013 found that prioritising and fostering mentoring relationships with colleagues influenced "educator identity in practice and was evident in the shift in educator identity in practice towards valuing productive relationships in terms, creating a supportive culture in which people felt safe to ask for support and offer support" (Morgan, et, al, 2013, p. 264). When developing induction frameworks, PLs need to take the time to develop trusting relationships, to ensure that professional identity continues to evolve within their new RTLB. Their ideas and experiences should be validated (Day et al., 2006; Sowder, 2007).

\section{The Role of Communities of Practice (COP)}

COP are "groups of people who share a concern or a passion for something they do and learn how to do it better as they interact regularly" (Wenger, \& Trayner, 2015 , p. 1). Researchers have identified the important role COPs play in the emergence and shaping of teacher identity (McGregor et al. 2010; Murray, 2008;
Poyas \& Smith, 2007). They argue that teacher's identity is partially formed by their participation and discussions within a COP that provides opportunities for teachers to learn with and from others (Borko, 2004; Chou, 2011; Lieberman \& Pointer Mace, 2008)

COP can also play an essential role within the induction framework of new RTLB as they allow RTLB to co-construct new ideas, share skills and learning, explore best practice and methodologies (Murray, 2008; Poyas \& Smith, 2007) While PLs are not always the facilitator of COP, their role is multi-faceted. For some, the balance between meeting the needs of new RTLB and their ability and confidence to support and meet those needs are at odds. When establishing COP as part of induction frameworks, PLs need to ensure that they can guide reflection and work successfully in a group setting (Fresko \& Alhija, 2015). They also need to acknowledge that providing adequate time is vital. A significant concern and tension for new teachers is trying to find the time to engage in COP and professional development (Murray, 2008; Yeo, Bennett, McNichol \& Merkley, 2015).

\section{Impact/importance of Professional Learning}

Opportunities to participate in professional learning development (PLD) and personal inquiry also play an important role in the induction and the ongoing development of individual professional identity. Research shows that a lack of knowledge and an inability to develop the skills to inquire and reflect can be due to the absence of an effective induction programme (Murray, 2008; Poyas \& Smith, 2007; Williams \& Ritter, 2010). PLD, whether it is formal or informal, provides new RTLB with a foundation of support. Professional identity is not a 'fixed construct', and its formation is ongoing (Sachs, 2001). Through feedback, inquiry and PLD, new RTLB can reflect on their ways of being and becoming (Wenger, 1999).

\section{Cultural Contexts}

Cultural competence is the acquisition of skills so that we are better able to understand members of other cultures in order to achieve best outcomes .... it is about being able to understand the people who we are going to deal with, as practitioners (Durie, 2003, p. 3).

When looking at induction and supporting the professional identity of Maori, being cognisant that a framework that has been used for mentoring/ supporting Pākehā cannot and should not be imposed on another group, is vital. Research has shown that when inducting Maori within a Pākehā framework, participants need to be aware that if we layer one set of cultural values on those of another, unexpected outcomes such as resentment and dissension could 
be triggered (Raumati Hook, Waaka \& Parehaereone Raumati, 2007).

\section{METHODOLOGY}

A mixed method research framework was used for this study. By utilising this 'rigorous' approach (AramoImmonen, 2013), equal priority was able to be given to qualitative and quantitative research (Greene et al., 1989; Morgan, 1998; Steckler et al., 1992).

A mixed methods study involves the collection or analysis of both quantitative and/or qualitative data in a single study in which the data are collected concurrently or sequentially, are given a priority, and involve the integration of the data at one or more stages in the process of research (Creswell et al., 2003, p. 212).

By utilizing this mixed method framework; cross validation, confirmation or corroboration of findings could occur within the one study (Creswell, et al., 2003).

\section{Inquiry Questions}

The focus of the inquiry was to answer the following questions:

- How can I as a RTLB Practice Leader support the development of new RTLB professional identity through induction processes?

- What are the key indicators I as a Practice Leader will need to address within the induction process to support professional identity of new RTLB?

\section{Participation in the Study}

This inquiry took place across RTLB clusters ${ }^{3}$ throughout New Zealand over the period of approximately one year. Before the research commenced, the inquiry proposal was submitted to the Massey University Human Ethics Committee and was deemed to be 'low' risk. Due to the nature of the inquiry, two focus groups were selected: RTLB new to the service in the last three years, and, RTLB Practice Leaders who were responsible for the induction process within their cluster. This 'sampling approach' allowed for the elaboration of insight from a population of interest (Menter et al., 2011).

An invitation to participate with a link to the online surveys (see Appendices A \& B) was sent out to all forty RTLB cluster managers in New Zealand. I believed that the quality of the inquiry not only rested on the appropriateness of the methodology but also on the suitability of the sampling strategy

\footnotetext{
${ }^{3}$ A group of RTLB who are employed by a lead kura/school and its Board of Trustees (BoT) within a geographical area of New Zealand. Although all RTLB in one cluster will be employed by the lead kura/school's BOT, they may be located at other schools in the cluster area. (TKI, 2017)
}

(Cohen et al., 2007; Menter et al., 2011; Morrison, 1993; Mutch, 2013). By targeting my surveys to key RTLB who were involved with induction, I was ensuring that the data would be valid and relevant. Participation was voluntary and anonymous. It is unknown how many potential participants received the links; however, sixty surveys were completed with a response rate of 23 percent nationwide.

\section{Data collection}

The design framework used to gather data for the inquiry was the concurrent/convergent triangulation design (Figure 1) and the implementation of the data collection was concurrent; data was gathered simultaneously across the whole of New Zealand via online surveys.

\section{Three Basic Mixed Methods Designs Convergent Design}

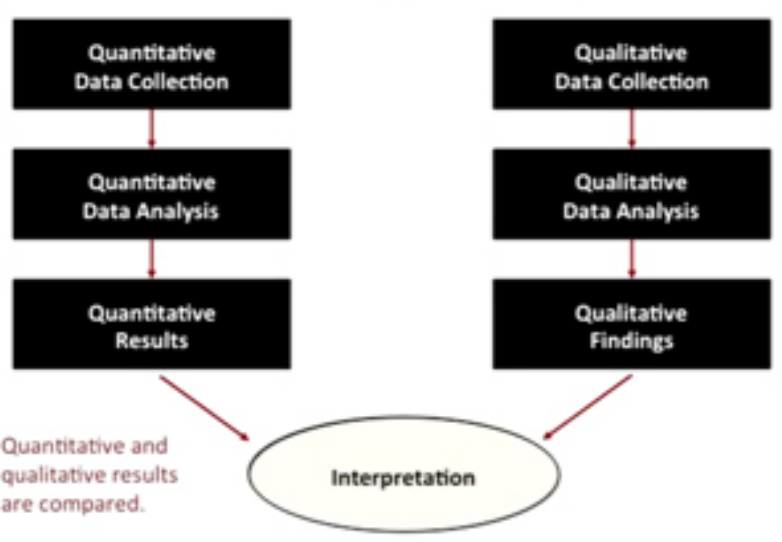

Figure 1. Three basic mixed methods designs. (Creswell, 2013)

A pilot of the online surveys was carried out prior to the inquiry by seven RTLB new to the service and two PLs within my cluster. I sought critical feedback, and then reframed questions and the layout accordingly. The pilot ensured that my surveys were not "fishing expeditions", but instead were "devices for measuring variables" (Bouma, 1996, p. 64). Questions were devised that would gather both 'hard' data (closed questions) and stories/perspectives (open questions) from participants. Questions were also devised that provided opportunities for the participants to rank factors they deemed to be important to include in their induction, including scales of satisfaction (Likert, 1932). After piloting the survey, Likert scales were changed from a 5 point scale to a 3 point scale.

The online surveys were 'open' for six weeks, and, during this time a reminder invitation was sent out to all RTLB cluster managers as the response rate was low (under 20 surveys completed). A possible factor 
at play was that the Education Review Office was conducting a nationwide review of the RTLB service during this period. Once the surveys were closed, the data was analysed over a period of five weeks, and the information was highlighted using concepts from the induction literature review as well as additional themes that continually arose across both PLs and new RTLB.

The thematic analysis of the data was guided by the initial inquiry questions (Menter et al., 2011). Themes were identified from the PLs and new RTLB surveys and then compared and interpreted together where appropriate. The thematic analysis allowed for the identification of developing connected views and ideas from both focus groups. This, in turn, allowed for common patterns to be labelled and isolated.

\section{RESULTS}

\section{Demographic Data}

Forty two new RTLB and eighteen PLs completed the online self-administered surveys. There was a geographical spread, with the majority of participants based in the North Island (71\%). The predominant ethnicities of participants were New Zealand European (61\%), Maori (24\%) and Pasifika (5\%), with 17 percent of the sample male and 83 percent female. The majority of RTLB clusters ranged from 41 percent having between 11-20 RTLB to 35 percent having 21-30 RTLB. Five percent worked in clusters with less than 10 RTLB.

The key themes that emerged from the data analysis in relation to the ways PLs can support the development of new RTLB's professional identity through induction processes were: consistency of induction; clarity and understanding around the nature of professional identity; developing and maintaining trusting relationships; the importance of ako, COP and the impact of RTLB training on professional identity.

\section{Consistency of Induction}

Disparity of induction frameworks. Induction frameworks and implementation varied markedly from cluster to cluster. While 91 percent of all participants (both new RTLB and PLs) indicated that their cluster had a formal induction process, over a quarter (26\%) stated that they had not participated formally in induction.

Impact of time. While 88 percent of all participants did meet formally around induction, the regularity and time dedicated to it varied greatly from cluster to cluster (Figure 2). Wanting consistency around meeting times was a recurring thread, e.g.. "I wish we did meet formally - usually it's on a need-to-know basis or just in time!" (RTLB 5). Some PLs reflected on the time they had put aside for induction and felt that while they had met when needed, they had no formal set times and dates and they now felt that "in hindsight maybe we should meet more formally" (PL 13).

\section{Frequency of Induction Meetings}



Figure 1. Frequency of Induction Meetings

Regular induction meetings that lasted between one and two hours were common (71\%), however, what was discussed varied greatly. References to induction in the RTLB Toolkit (2016) include certain expectations such as "induction includes familiarisation with the cluster needs analysis and strategic plan" (Ministry of Education, 2016, p. 43). A popular element within RTLB inductions nationwide was a focus on casework (85\%) and cluster procedures (41\%). New RTLB felt 'supported' and 'safe' within their new role when a high focus was placed upon cluster expectations.

Culturally appropriate. A commonality amongst participants was that the majority of new RTLB (95\%) felt that their induction was culturally responsive. New Maori RTLB felt that their PLs had a clear understanding around Maori pedagogy and that they were strengths-based and inclusive. Only three new RTLB felt that their cultures were not reflected within their induction. For them, it was only superficial elements such as having a karakia or kai at meetings that were deemed as 'important' by their PL.

\section{Clarity and Understanding of Professional Identity}

Lack of clarity around Professional Identity. Findings demonstrated a lack of clarity and understanding around the nature of professional identity and how it related to RTLB practice. Only a third of all participants felt that developing professional identity was part of the clusters induction framework, and another third were unclear if it was a focus at all. 
When asked if they had a clear understanding of what their professional identity as an RTLB was after participating in their clusters induction process, just under half of the 42 new RTLB (48\%) were able to answer yes, the rest were either unsure $(26 \%)$ or replied no (27\%). Feedback from some PLs indicated they had "never thought about including professional identity until now" (PL 18) and that it needs to be "done a lot better" (PL 16). There was similar feedback from new RTLB. For them, key themes were: "I wish our induction covered professional identity" (RTLB 5); "it is so important to look at professional identity as part of induction" (RTLB 23) and, "it would be good if it was consistent across the country rather than ad hoc as it appears to be now" (NRTLB 30).

Important Factors. In relation to the development of professional identity, new RTLB and PLs were asked to rank those factors they deemed to be essential aspects of an induction framework that would support the development of professional identity (Table 1). These factors were sourced from the literature review. There was a similarity of ranking from both new RTLB and PLs, which was encouraging. As can be seen from Table 1, there were key factors which all respondents identified as important. These will be examined further below.

Table 1: Important Factors $(\mathbf{n}=\mathbf{6 0})$

\begin{tabular}{|l|c|c|c|}
\hline $\begin{array}{l}\text { Important Factors } \\
\text { to be included }\end{array}$ & $\begin{array}{c}\text { New } \\
\text { RTLB } \\
(\mathbf{n = 4 2 )}\end{array}$ & $\begin{array}{c}\text { Practice } \\
\text { Leaders } \\
(\mathbf{n = 1 8})\end{array}$ & $\begin{array}{c}\text { Combined } \\
(\mathbf{n = 6 0 )}\end{array}$ \\
\hline $\begin{array}{l}\text { Being mentored } \\
\text { by an experienced } \\
\text { RTLB }\end{array}$ & $37(88.1 \%)$ & $\begin{array}{c}18 \\
(100 \%)\end{array}$ & $55(91.6 \%)$ \\
\hline $\begin{array}{l}\text { Having } \\
\text { opportunities to } \\
\text { co-work cases with } \\
\text { experienced RTLB }\end{array}$ & $\begin{array}{c}(81 \%) \\
14 \%)\end{array}$ & $52(86.6 \%)$ \\
\hline $\begin{array}{l}\text { Having a trusting } \\
\text { relationship with } \\
\text { inductor (Practice } \\
\text { Leader, etc.) }\end{array}$ & $37(88.1 \%)$ & $14(77.8 \%)$ & $\begin{array}{c}51 \\
(85 \%)\end{array}$ \\
\hline $\begin{array}{l}\text { Receiving feedback } \\
\text { around RTLB } \\
\text { practice }\end{array}$ & $36(85.7 \%)$ & $12(66.7 \%)$ & $\begin{array}{c}48 \\
(80 \%)\end{array}$ \\
\hline $\begin{array}{l}\text { Having a } \\
\text { Community of } \\
\text { Practice that looks } \\
\text { at professional } \\
\text { identity }\end{array}$ & $33(78.6 \%)$ & $11(61.1 \%)$ & $44(73.3 \%)$ \\
\hline $\begin{array}{l}\text { Previous skills } \\
\text { and knowledge } \\
\text { are valued and } \\
\text { recognised. }\end{array}$ & $31(73.8 \%)$ & $12(66.7 \%)$ & $43(71.6 \%)$ \\
\hline
\end{tabular}

\begin{tabular}{|l|c|c|c|}
\hline $\begin{array}{l}\text { Having formal } \\
\text { opportunities to } \\
\text { participate in PLD } \\
\text { to support RTLB } \\
\text { work. }\end{array}$ & $30(71.4 \%)$ & $12(66.7 \%)$ & $\begin{array}{c}42 \\
(70 \%)\end{array}$ \\
\hline $\begin{array}{l}\text { Direct links } \\
\text { are made to } \\
\text { professional and } \\
\text { evidence based } \\
\text { literature around } \\
\text { professional } \\
\text { identity. }\end{array}$ & $23(54.8 \%)$ & $10(55.6 \%)$ & 33 \\
\hline $\begin{array}{l}\text { Expectation that } \\
\text { they will enrol } \\
\text { in the Post Grad } \\
\text { Diploma in } \\
\text { Specialist Teaching } \\
\text { as soon as possible. }\end{array}$ & $15(35.7 \%)$ & $8(44.4 \%)$ & $23(38.3 \%)$ \\
\hline
\end{tabular}

\section{Developing and Maintaining Trusting Relationships}

Relationship with Practice Leader. In most cases, PLs were the key personnel in charge of implementing induction of new RTLB (74\%). Both new RTLB and $\mathrm{PLs}$ reported that the relationship between them was for the most part, very positive: "My Practice Leader and I get on very well - it wouldn't have worked nearly as well if we didn't" (RTLB 17). New RTLB reported that they felt able to go to their PL for advice and guidance and that the relationships they formed were "strong" and were "built and established quickly" (RTLB 31).

The role of mentors. Alongside the PL, some clusters employed mentors or tuakana buddies to support new RTLB, especially within their first year (18.7\%). These mentors/ buddies often only had a few more years' experience than the new RTLB and the support provided was, in the main, less formal and more responsive to need and current situations. New RTLB discussed how, through this intervention, they felt they were able to approach them often and that "manaakitanga" was at the heart of the relationships. (RTLB 35, 37, 39). Providing a mentor or 'go-to' person was also seen as a very valuable aspect of their induction and assisted with the growth of their professional development. New RTLB reported that having a buddy or mentor that they could access when needed ensured that they were "receiving affirmations" (RTLB 37) and had "peer to peer discussions" (PL 18).

\section{The Importance of Ako}

Ako. The notion of ako is described by the Ministry of Education as a relationship where the educator is also learning from the student and that participants are learning and sharing at the same time (Ministry 
of Education, n.d.) The importance and value of this was highlighted by 90 percent of all participants, particularly in relation to new RTLB having an ako relationship with an experienced RTLB. This was usually either a PL or an experienced RTLB within the cluster who new RTLB felt they could 'trust'.

Co Working. Having the opportunity to authentically co-work cases with experienced RTLB was seen as invaluable by all participants. "The best part of my induction so far" (RTLB 9). Over 41 percent of new RTLB reported that they were provided with the opportunity to co-work one or more cases and that this was extremely beneficial. Others (27\%) explained how they were able to 'shadow' colleagues and see the various RTLB phases in 'action'.

Feedback. For many new RTLB and PL respondents $(78 \%)$, receiving feedback from their $\mathrm{PL}$ or experienced RTLB was deemed as an essential aspect of their induction. However; there was a variation around the type of feedback new RTLB reported receiving. (Figure 2)

\section{Types of Feedback Provided}

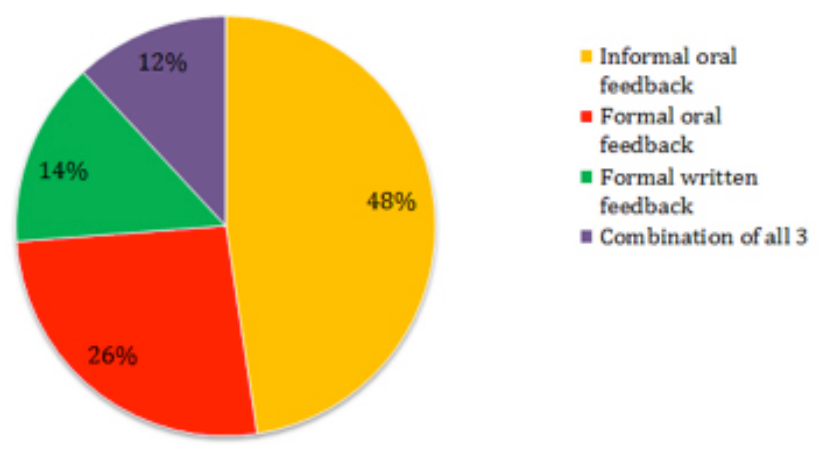

Figure 2. Types of Feedback Provided

\section{Communities of Practice}

Regularity of COP Meetings. Although many participants felt that a lack of time was a key factor within their induction framework, the majority of clusters (88.3\%) provided some form of a COP, with a focus on induction. As discussed earlier, (Figure 1.2) the regularity of these meetings varied across the country. However, there were some key themes that were identified as being important. One of these was the value of providing opportunities for questions to be asked - "having a forum to talk and ask questions .... can bounce ideas off each other" (RTLB 15). It is important to note here that this was indicated by the new RTLB participants (26.8\%); Not one PL indicated that they felt providing a question and answer section within their COP was important.
Recognising Prior Knowledge and Skills. Ninetythree percent of all participants felt that their clusters recognised and valued their prior teaching skills and knowledge, and that this was often supported through COP meetings "I have never felt inexperienced, or under-qualified, all of our ideas are listened to and respected" (RTLB 37). PLs shared that these prior skills and knowledge were at the forefront when they allocated cases to their new RTLB. They also stated how this enhanced their clusters capability (28\%) and supported national priorities such as supporting Maori teachers, students and whānau.

\section{The Impact of RTLB Training on Professional Identity}

Disparity with Postgraduate Study. Nearly two thirds of PLs $(61 \%)$ stated that they were making 'explicit links' to the content covered in the postgraduate qualification, However, only 41 percent of new RTLB reported the same thing. Overall, only 47.4 percent of new RTLB believed that direct links had been made to the postgraduate qualification content as part of their induction. Forty-four percent of PLs gained their RTLB qualification prior to 2014, and 38 percent of new RTLB had yet to start the RTLB postgraduate study.

\section{DISCUSSION}

\section{Consistency of Induction}

One of the key findings was a disparity across the country in regards to the frameworks clusters use for induction of new RTLB. A possible reason for this is that while the revised RTLB Toolkit (2016) has certain expectations regarding the induction of new RTLB, there is no detailed framework or principles around induction.

A theme both new RTLB and Practice Leaders discussed within the research was the impact of time constraints on induction. This concern and tension around trying to find the time to engage in COP is not uncommon (Murray, 2008; Yeo, Bennett, McNichol \& Merkley, 2015). When we reflect on the variation across clusters around time given to induction, it could be argued that PLs need to acknowledge and ensure that they are providing adequate time for induction.

It was somewhat surprising that access to and unpacking of the RTLB Toolkit (14.2\%), professional readings $(16 \%)$, a focus on wellbeing $(11.9 \%)$, opportunities to share best practice $(7.1 \%)$ and cultural issues $(2.3 \%)$ were seen as low priorities. It would appear from this research that the majority of RTLB induction frameworks focus more on a 'tick list' of tasks to become familiar with (policies and procedures), rather than being a robust, authentic experience to allow growth and a transition into a 
new profession (Gujarati, 2012; Kang \& Berliner, 2012; Kearney, 2013; Serpell, 2000; Wojnowski, Bellamy \& Cooke, 2003).

\section{Clarity and Understanding Around the Nature of Professional Identity}

Surprisingly, 50 percent of PLs stated that they did not formally include a focus on professional identity within their induction framework and only eight percent said it was a natural part of their induction process. This ambiguity around the inclusion of professional identity is concerning. If PLs are saying that professional identity "is not clearly identified within the induction process" (PL 9), then it is not surprising that new RTLB are feeling unsupported around this (56.6\%). Davey (2010) talks about a career on the cusp. For him, this 'on the cusp' phrase equates to the idea of "a professional life spent on the 'verge' of a community on the periphery, the edges, or the fringes, rather than at the centre" (p. 3). New RTLB, it could be argued as also 'on the cusp' and are in a time of change. PLs would be able to support this process of re-formation if they themselves have a clear understanding of the professional identity of RTLB.

\section{Developing and Maintaining Trusting Relationships}

One important aspect of an effective induction framework that supports the development of professional identity is the formation of collaborative relationships between participants. Lave and Wenger (1991) contest that learning involves the whole person and that the relationship that exists and the learning that occurs define that person. This could be argued to be true for induction and identity. If nearly three quarters of clusters within New Zealand have a PL facilitating the induction process $(74 \%)$, we would expect to see the development of professional identity within our new RTLB; yet this is not the case. Fifty-two percent of all participants reported that they were either unsure of or did not know what their professional identity was. One of the core purposes of mentoring is to develop professional identity (Dobrow \& Higgins, 2005; Hall \& Burns, 2009; Kram, 1985). By providing emotional and academic support through establishing positive relationships and mentoring, PLs would be ensuring they are helping to build professional identity through induction.

\section{The Importance of Ako}

Having opportunities to learn from more experienced RTLB, whether it be co-working or shadowing with casework, was clearly identified by all participants as being very effective around assisting with the development and growth of new RTLB professional identity. The importance of induction involving opportunities for situated learning is reflected in these findings. Lave and Wenger (1991) highlight the significance of newcomers being able to interact with more experienced colleagues, both formally and informally. This situational learning allows new RTLB to co-construct their professional identities through listening to others' experiences and having their experiences validated (Day et al., 2006; Sowder, 2007; Williams \& Ritter, 2010).

The importance of new RTLB receiving feedback from their PL or experienced RTLB was highlighted through this research. Professional identity is not a "fixed construct" but one that evolves and is ongoing (Sachs, 2001). We know that through effective, ongoing feedback, new teachers/RTLB can reflect on their ways of being and becoming (Wenger, 1999). This research reinforces the critical role feedback plays on learning (Hattie, 2016) and identity development (Sachs, 2001), and therefore, we could argue, should form part of effective induction.

\section{Communities of Practice}

This research reinforced the notion that COP play an essential role within the induction framework of new RTLB by offering opportunities for teachers to share new knowledge, tools, methods, activities and materials (Poyas \& Smith, 2007) to complete team planning, teaching and supervision (Murray, 2008) and develop social interaction with other members of the community (McGregor et al., 2010). It highlighted that for PLs and new RTLB, COP allowed for professional dialogue to occur around the RTLB Practice Sequence (28.5\%) and the unpacking of professional literature (35\%). New RTLB did not appear to see their involvement in COP as a mentoring situation or an opportunity to share best practice; rather, it was an occasion to clarify casework $(85 \%)$ and answer queries around study (35\%).

Within a COP the role of the facilitator is key. Their position requires them to be skilled in "group dynamics, emotionally intelligent, knowledgeable of how to promote reflection and skilled in coordinating group activities" (Fresko, \& Alhija, 2015, p. 37). PLs; need to be cognisant of this when establishing their RTLB induction programmes and their COP.

\section{The Impact of RTLB Training on Professional Identity}

A key finding from the research was that there is disparity across the country in regards to the support and explicit links made within the induction frameworks to the RTLB post-graduate study offered through Massey and Canterbury universities. Of interest is the disconnect between what PLs believed they were covering $(61 \%)$ within their induction and what new RTLB reported was occurring (41\%). A more collaborative approach around the inclusion 
of the content covered in the RTLB post-graduate qualification and a national RTLB induction framework, may allow individuals to become more agentic through effective feedback and support. It may also enable them to explore their changing identity with others (Hattie, 2016; Latta \& Buck, 2007; Mutton, et al., 2011; Sachs, 2001).

It is interesting to note that of the eighteen PLs who participated in this research, nearly half of them gained their RTLB qualification prior to 2014. This, alongside the fact that 38 percent of new RTLB have yet to commence the RTLB study, may have contributed to the disparity across the country concerning induction and a perceived lack of explicit links made to the formal qualification within the induction frameworks. For those RTLB and PLs who had started or completed the post-graduate qualification, it is clear that links and connections have been made: "It has only been since starting study that pieces of the puzzle have started to come together" (RTLB 34) and "I did not really see the connection until I started studying" (RTLB 3).

\section{CONCLUSIONS AND RECOMMENDATIONS}

This research has highlighted some of the key factors that need to be considered when supporting the evolvement of professional identity through induction. The lack of clarity around what professional identity is needs to be addressed nationwide. PLs need to ensure that they have a clear understanding around what professional identity is as they assist new RTLB who are 'on the cusp' (Davey, 2010) of change.

It is clear that to develop professional identity as a new RTLB, PLs need to ensure that their induction process is robust. It is not a 'tick list' of tasks to become familiar with; instead, it is endeavoring to provide authentic feedback and COP that allow new RTLB to challenge assumptions and make new connections within a safe and secure environment. This process takes time. It is not a one-off event occurring within the early stages of their RTLB career (first few months), but rather that it should be ongoing and integrated into their professional learning journey.

Cluster managers and PLs needs to ensure that induction is valued and that time is put aside for COP meetings and attending PLD/training. However, alongside this is another vital component establishing trusting relationships. It is essential that PLs know and value the prior skills and experiences their new RTLB bring with them to the cluster and use culturally- responsive frameworks of support.
Although this research took place nationwide, it must be noted that not all RTLB clusters, PLs and new RTLB to the service participated. It would be interesting to explore the relevance of these findings across all clusters, with the view of the RTLB service having a unified induction framework that not only supports but fosters the professional identity of new RTLB.

Ultimately this research indicates the important role PLs play in the development of new RTLB professional identity through induction. Induction is "the primary phase in a continuum of professional development leading to the teacher's full integration into a professional community of practice and continuing professional learning throughout their career" (Kearney, 2013. p. 29). The ultimate aim of an effective induction programme is to enhance the new teachers' skills and levels of self-efficacy (Ingersoll, 2012). This, in turn, ensures they "gain and develop a professional identity" (Feiman-Nemser, 2001, p. 1026). This study suggests that more emphasis and understanding around the role of induction and its impact on the development of professional identity of new RTLB is urgently needed. 


\section{REFERENCES}

Aramo-Immonen, H. (2013). Mixed methods research design. In Information systems, e-Learning, and knowledge management research (pp. 32-43). Springer.

Bandura, A. (1977). Self-efficacy: Toward a unifying theory of behavioural change. Psychological Review, 84(2), 191-215.

Bandura, A. (1989). Regulation of cognitive processes through perceived self-efficacy. Developmental Psychology, 25(5), 729-735.

Beijaard, D., Meijer, P. C., \& Verloop, N. (2004). Reconsidering research on teachers' professional identity. Teaching and Teacher Education, 20, 107-128

Berger, P., \& Luckmann, T., (1991). The social construction of reality: A treatise in the sociology of knowledge (No. 10). London: Penguin.

Bickmore, D., \& Bickmore, S. (2010). A multifaceted approach to teacher induction. Teaching and Teacher Education, 26, 1006-1014

Bouma, G. (1996). The research process (3rd ed.). Melbourne: Oxford University Press.

Borko, H. (2004). Professional development and teacher learning: Mapping the terrain. Educational Researcher, 33(8), 3-15.

Britton, E., Paine, L., Pimm, D., \& Raizen, S. (2003). Comprehensive teacher induction. Dortrecht: Kluwer Academic Press.

Carroll, T. G., Fulton, K., Yoon, I., \& Lee, C. (2005). Induction into learning communities. U.S. Department of Education. ERIC.

Chou, C. (2011). Teacher's professional development: Investigating teachers' learning to do action research. The Asia-Pacific Education Researcher, 20(3), 421-437.

Conway, C. (2009). Effective teacher induction and mentoring: Assessing the evidence. Journal Of Music Teacher Education, 19(1), 93-104.

Cohen, L., Manion, L., \& Morrison, K. (2007). Research methods in education. London: Routledge.

Creswell, J. (2013). What is mixed methods research. Available from: https://www.youtube.com/watch?v $=1$ OaNiTlpyX8\&feature=player_embedded

Davey, R.L., (2010) Career on the cusp: The professional identity of teacher educators, $\mathrm{PhD}$ thesis, University of Canterbury, Christchurch, New Zealand.
Day, C., Kington, A., Stobart G., and Sammons P. 2006. The personal and professional selves of teachers: Stable and unstable identities. British Educational Research Journal. 32 (4): 601-616.

Day, C. (1999). Developing teachers, The challenge of lifelong learning. London: Falmer.

Dewey, J. (1933). How we think: A restatement of the relation of reflective thinking to the educational process. Lexington, MA: Heath.

Dobrow, S. R., \& Higgins, M. C. (2005).

Developmental networks and professional identity: A longitudinal study. Career Development International, 10(6/7), 567-583.

Duffin, L. C., French B. F., \& Patrick, H. (2012). The teachers' sense of efficacy scale: Confirming the factor structure with beginning pre-service teachers. Teaching and Teacher Education: An International Journal of Research and Studies, 28(6), 827-834.

Education Council (2017). Available from: https:// educationcouncil.org.nz/content/practisingteacher-criteria

Feiman-Nemser, S.(2001). From preparation to practice: Designing a continuum to strengthen and sustain teaching. Teachers College Record 103(6), 1013-1055

Feiman-Nemser, S., Carver, C, Schwille, S., \& Yusko, B. (1999). Beyond support: Taking new teachers seriously as learners. In M. Scherer (Ed.), A better beginning: Supporting and mentoring new teachers (pp. 8-12). Alexandria, VA: Association for Supervision and Curriculum Development.

Fresko, B., \& Alhija, F. N. (2015). Induction seminars as professional learning communities for beginning teachers. Asia-Pacific Journal of Teacher Education, 43(1), 36-48.

Fresko, B., \& Alhija, F. N. (2015). Induction seminars as professional learning communities for beginning teachers. Asia-Pacific Journal of Teacher Education,43(1), 36-48.

Garvis, S. (2009). Establishing the theoretical construct of pre-service teacher self-efficacy for arts education. Australian Journal of Music Education, $1,29-37$.

Greene, J.C., Caracelli, V. J., \& Graham, W. F. (1989). Towards a conceptual framework for mixedmethod evaluation designs. Educational Evaluation and Policy Analysis, 11, 255-274. 
Gujarati, J. (2012). A comprehensive induction system: A key to the retention of highly qualified teachers. The Educational Forum, 76, 218-223.

Hall, L. A., \& Burns, L. D. (2009). Identity development and mentoring in doctoral education. Harvard Education Review, 79(1), 49-70.

Hattie, J. (2016) Available from: http://www. evidencebasedteaching.org.au/hattie-effect-size2016-update/

Hattie, J., \& Timperley, H. (2007) The power of feedback. Review of Educational Research, 77, 81-112.

Henry, G. T., Bastian, K. C., \& Fortner, C. K. (2011). Stayers and leavers: Early-career teacher effectiveness and attrition. Educational Researcher, 40(6), 271-280.

Hsieh, B. (2014). The importance of orientation: Implications of professional identity on classroom practice and for professional learning. Teachers and Teaching: Theory and practice, 21(2), 178-190.

Ingersoll, R. M. (2012). Beginning teacher induction: what the data tell us. Phi Delta Kappan, 93, 47e51.

Kang, S., \& Berliner, D. C. (2012). Characteristics of teacher induction programs and turnover rates of beginning teachers. The Teacher Educator, 47, 268-282.

Kearney, S. (2013). New Scheme Teacher induction: Challenges and opportunities. Saarbrucken: Scholar's Press.

Kelchtermans, G. (2009). Who I am in how I teach is the message: Self-understanding, vulnerability and reflection. Teachers and Teaching, 15, 257-272.

Kerby, A. (1991). Narrative and the self. Bloomington: Indiana University Press.

Kreber, C. (2010). Academics' teacher identities, authenticity and pedagogy. Studies in Higher Education 35 (2): 171-194.

Latta, M., \& Buck, G. (2007). Professional development risks and opportunities embodied within self-study. Studying Teacher Education, 3(2), 189-205.

Lave, J., \& Wenger, E. (199). Situated Learning: Legitimate peripheral participation. New York: Cambridge University Press.

Lieberman, A., \& Pointer Mace, D.H. (2008). Teacher learning: The key to educational reform. Journal of Teacher Education, 59(3), 226-234.
Lerman, S. (2009). Pedagogy, discourse and identity. In mathematical relationships in education.

Identities and participation, edited by L. Black, $\mathrm{H}$. Mendick, and Y. Solomon, 147-159. New York: Routledge.

Luehmann, A. L. (2007), Identity development as a lens to science teacher preparation. Sci. Ed., 91, 822-839.

Luft, J. A. (2007). Minding the gap: Needed research on beginning/newly qualified science teachers. Journal of Research in Science Teaching, 44(4), 532-537.

McGregor, D., Hooker, B., Wise, D., and Devlin, L. (2010). Supporting professional learning through teacher educator enquiries: An ethnographic insight into developing understandings and changing identities. Professional Development in Education 36 (1-2): 169-195.

Menter, I., Elliot, D., Hulme, M., Lewin, J., \& Lowden, K. (2011). A guide to practitioner research in education. Thousand Oaks, CA: SAGE Publications.

Ministry of Education (2016). Professional practice toolkit Available from: TKI: file://N:/RTLB\%20 Professional\%20Practice\%20Toolkit\%20(2).pdf

Ministry of Education (2015). Resource teacher: Learning and behaviour online. Available from http://rtlb.tki.org.nz/The-RTLB-service/Cluster-leadschool-and-areas

Morgan, D. (1998). Practical strategies for combining qualitative and quantitative methods: Applications to health research. Qualitative Health Research, 8, 362-376.

Morgan, A., Brown, R., Heck, D., Pendergast, D., \& Kanasa, H. (2013). Professional identity pathways of educators in alternative schools: The utility of reflective practice groups for educator induction and professional learning. Reflective Practice, 14(2), 258-270.

Morrison, K. R. B. (1993). Planning and accomplishing school-centred evaluation. Dereham, UK: PeterFrancis.

Murray, J. (2008). Teacher educators' induction into higher education: Work-based learning in the micro communities of teacher education. European Journal of Teacher Education 31 (2), 117-133.

Mutch, C. (2013). Doing educational research. A practitioner's guide to getting started. 2nd edition. Wellington: NZCER. 
Mutton, T., Haeger, H., \& Burn, K. (2011). Learning to plan, planning to learn: The developing expertise of beginning teachers. Teachers and Training. 17(4), 399-416.

NZTC (2015). Guidelines for induction and mentoring and mentor teachers 2015. Wellington, N.Z.: New Zealand Teachers Council.

Palmér, H. (2016). Professional primary school teacher identity development: A pursuit in line with an unexpressed image. Teacher Development, 20(5), 682-700.

Ponte, J. P., \& Chapman., (2008). Preservice mathematics teachers' knowledge and development. In Handbook of International Research in Mathematics Education, edited by L. D. English, M. B Bussi, G. A. Jones, R. A. Lesh, B. Sriraman, and D. Tirosh, 223-261. London: Routledge.

Poyas, Y, \& Smith, K. (2007). Becoming a community of practice - The blurred identity of clinical faculty teacher educators. Teacher Development 11 (3): 313-334.

Raumati Hook, G., Waaka, T., \& Parehaereone Raumati, L. (2007). Mentoring Māori within a Pākeha framework. MAI Review, 2007, 3, Target Article 1.

Ross, J., \& Bruce, C. (2007). Professional development effects on teacher efficacy: Results of randomized field trial. The Journal of Educational Research, 101(1), 50-60.

Ruohotie-Lyhty, M. (2013). Struggling for a professional identity: Two newly qualified language teachers' identity narratives during the first years at work. Teaching And Teacher Education, 30120-129.

Sachs, J. (2001). Teacher professional identity: Competing discourses, competing outcomes. Journal of Education Policy 16 (2): 149-161.

Saka, Y., Southerland, S. A., \& Brooks, J. S. (2009). Becoming a member of a school community while working toward science education reform: Teacher induction from a cultural historical activity theory (CHAT) perspective. Science Education, 93(3), $1-30$.

Schifter, D. (1996). Whats's Happening in Math Class? Envisioning New Practices through Teacher Narratives. New York: Teachers College Press.

Serpell, Z. (2000). Beginning teacher induction: A review of the literature. Washington, DC: American Association of Colleges for Teacher Education.
Settlage, J., Southerland, S.A., Smith, L.K., \& Ceglie, R. (2009). Constructing a doubt-free teaching self: Self-efficacy, teacher identity and science instruction within diverse settings. Journal of Research in Science Teaching, 46(1), 102-125.

Sowder, J. T. 2007. The mathematical education and development of teachers. In Second Handbook of Research on Mathematics Teaching and Learning, edited by F. K. Lester, 157-224.

Steckler, A., McLeroy, K. R., Goodman, R. M., Bird, S. T., \& McCormick, L. (1992). Towards integrating qualitative and quantitative methods: An introduction. Health Education Quarterly, 19)1), 1-8.

Totterdell, M., Bubb, S., Woodroffe, L., \& Hanrahan, K. (2004). The impact of newly qualified teachers (NQT) induction programmes on the enhancement of teacher expertise, professional development, job satisfaction or retention rates: A systematic review of the literature on induction. London: EPPICentre, Social Science Research Unit, University of London.

Tschannen-Moran, M., Hoy, A. W., \& Hoy, W. (1998). Teacher efficacy: Its meaning and measure. Review of Educational Research, 68(2), 202-248.

Wenger, E. (1999). Communities of practice: Learning, meaning, and identity. Cambridge: Cambridge University Press.

Williams, J, \& Ritter, J, .(2010). Constructing new professional identities through self-study: From teacher to teacher educator. Professional Development in Education, 36 (1-2): 77-92.

Wojnowski, B. S., Bellamy, M. L., \& Cooke, S. (2003). A review of literature on the mentoring and induction of beginning teachers with an emphasis on the attrition and renewal of science teachers. In J. Rhoten \& B. Powers (Eds.), Science teacher attrition: Mentoring and renewal (pp. 23-33). Washington, DC: National Science Teachers Association.

Yeo, M., Bennett, D., McNichol, J. S., \& Merkley, C. (2015). New faculty experience in times of institutional change. Canadian Journal Of Higher Education, 45(4), 283-297. 


\section{Jo Arnold}

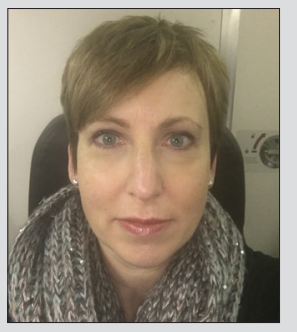

Jo Arnold is an RTLB Practice Leader from Cluster 21 based in Gisborne. Prior to this, she worked as a primary teacher in numerous schools in New Zealand, Singapore and England where she was a deputy and assistant principal and/or SENCO. Jo has just completed her Masters in Specialist Teaching and has an interest in mentoring, developing and supporting professional identity in new teachers/ RTLB.

Email: rtlb.joarnold@gmail.com 